Copyright (C) 2021 by Cherkas Global University

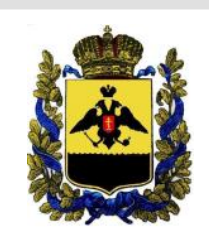

Published in the USA

Bylye Gody

Has been issued since 2006.

E-ISSN: 2310-0028

2021. 16(4): 1615-1623

DOI: $10.13187 /$ bg.2021.4.1615

Journal homepage:

https://bg.cherkasgu.press

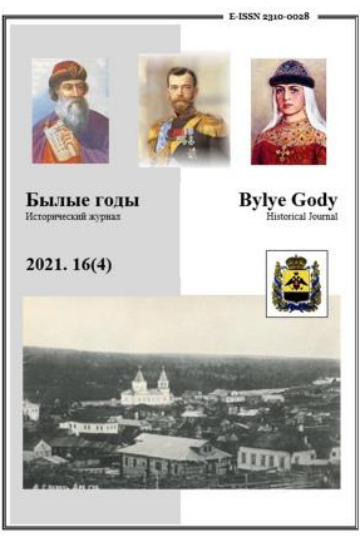

\title{
Shipbuilding in the Voronezh Region during a Petrovsky Epoch and Its Influence on Growth of Enterprise Activity
}

\author{
Natalia A. Dushkova a , *, Larisa I. Maslikhova a \\ a Voronezh state technical university, Russian Federation
}

\begin{abstract}
The article is devoted to the problem of the growth of entrepreneurial activity in Voronezh region as the result of shipbuilding. It manifested itself primarily in the construction of private metallurgical plants, cloth factories. The authors disclose state measures to support private owners, characterize the advantages of private enterprises over the state. Some attention is paid to the identification of the reasons for the conservation and further development of a wide range of fisheries along with manufacturing.

A large place in the article is devoted to the process of expanding the entrepreneurial layer in trade. The social composition of Voronezh merchants was investigated, the fact of the increased specialization of the trading layer in the Petrine period was noted.

The authors emphasize the special importance of agriculture during shipbuilding in Voronezh, which becomes the main branch of the economy of the Voronezh Territory. They identify three categories of the population that have shown entrepreneurial activity in this area and have significantly succeeded in their work.

The work shows positive results from entrepreneurial activity, indicates the advantages gained by different categories of the population from this activity, shows the economic effect.

Keywords: shipbuilding, entrepreneurship, production, manufacturing, metallurgy, crafts, artisans, merchants, agriculture.

\section{1. Введение}

В текущем году Россия отмечает 325-ю годовщину начала строительства собственного военноморского флота. Отдавая дань памяти русскому императору Петру I, который стал инициатором кораблестроения, важно также подчеркнуть значимость социально-экономических преобразований, которые затем последовали. Речь идет о подъеме мануфактурного производства, развитии сельского хозяйства и животноводства, расширении торговли, распространении товарно-денежных отношений, активизации предпринимательской деятельности среди различных слоев населения. Все эти процессы особенно заметны были в Воронежском крае, так как Воронеж являлся объектом повышенного интереса Петра I в связи с начавшимся здесь в конце XVII века строительством флота.

События тех времен убедительно свидетельствуют о том, что строительство военно-морского флота имело значение не только для решения внешнеполитических задач, но и послужило драйвером для активизации предпринимательской деятельности даже в условиях сохранения феодального строя.

В связи с этим есть смысл обратиться к прошлому опыту петровской эпохи и на примере Воронежского края рассмотреть, как повлияло кораблестроение на экономическую жизнь региона, на предпринимательскую деятельность.
\end{abstract}

\footnotetext{
${ }^{*}$ Corresponding author

E-mail addresses: dushkova12@mail.ru (N.A. Dushkova)
} 


\section{2. Материалы и методы}

Источниковая база исследования представлена документами Государственного архива Воронежской области (Воронеж, Российская Федерация), из которых в основном были проанализированы материалы Воронежской казенной палаты (Фонд И-18), Воронежского наместнического правления (Фонд И-14), Азовской приказной палаты (Фонд И-5), Павловского городового магистрата (Фонд И-257), Приказа адмиралтейских дел (Фонд И-171). Привлеченные к работе документы позволили выяснить, какие категории населения проявляли наибольшую предприимчивость, за счет кого пополнялись их ряды, каким образом они взаимодействовали между собой и какую часть населения края они составляли. Исследование архивных материалов дало возможность также получить информацию о рабочей силе первых металлургических заводов, о наличии тех или иных промыслов, о роли государства в деятельности предпринимательского слоя, о положении крестьян и их конфликтах с помещиками, бегстве крестьян.

Решение исследовательских задач осуществлялось с помощью принципа историзма. Он позволил проанализировать процесс развития предпринимательского слоя в Воронежском крае, выявить его сильные и слабые стороны, оценить характер его взаимодействия с различными экономическими, социальными и политическими институтами.

В стремлении реализовать принцип научной объективности была предпринята попытка избавиться от односторонних взглядов на деятельность предпринимателей, их роль в экономическом развитии региона.

Кроме того, при исследовании темы использовался сравнительный метод, который позволял сопоставлять факты и их анализировать. Статистический метод способствовал выявлению количественных показателей, определению численности различных категорий населения. Все это дало возможность осуществить исследование темы, обобщить материал и сформулировать выводы.

\section{3. Обсуждение}

Тема о предпринимательской деятельности в Воронежском крае в Петровскую эпоху по-прежнему остается малоизученной, хотя ее исследование началось еще в дореволюционный период. Труды первых воронежских краеведов Г.М. Веселовского (Веселовский, 1866; Веселовский, 1886) и Л.Б. Вейнберга (Вейнберг, 1885; Вейнберг, 1890) в большей мере имели информационный характер и основаны были на документах статистического комитета. Авторы, не делая каких-либо выводов и тем более не выдвигая цели исследования истории предпринимательства, дали большой объем фактического материала, касающийся торгово-промышленной и сельскохозяйственной деятельности воронежцев. Главную задачу они видели в том, чтобы накопить статистические сведения для создания в будущем обобщающих трудов.

В советское время заниматься исследованием истории российского предпринимательства было не принято. Выходили работы, посвященные или истории края, или развитию отдельных отраслей экономики: например, «Очерки истории Воронежского края» под ред. Е.Г. Шуляковского (Шуляковский, 1961), публикация В.И. Недосекина, посвященная металлургической промышленности Черноземного Центра России в XVIII в. (Недосекин, 1960), труд В.М. Проторчиной о развитии суконной промышленности в Воронеже в XVIII веке (Проторчина, 1961).

Некоторое оживление интереса к исследованию предпринимательства произошло в конце XX века, что было обусловлено возрождением в России товарно-денежных отношений. Был опубликован обобщающий труд в двух книгах под редакцией А.В. Семеновой, посвященный истории российского предпринимательства (История предпринимательства..., 2000).

Активизировалась работа в данном направлении и в Центральном Черноземье. Вышел в свет труд Ю.А. Мизиса, в котором раскрываются характерные особенности зарождения рыночных отношений в данном регионе, показана роль посадского и служилого населения в ходе формирования купеческого слоя (Мизис, 2006). Была опубликована монография В.А. Григоровой, где анализируется процесс создания первых металлургических предприятий на Черноземном Юге на основе кустарных промыслов, дается оценка роли кустарей в качестве мастеровых людей на крупных заводах (Григорова, 2011). Целую серию статей опубликовала О.И. Павличенко, в которых анализируется процесс зарождения и развития предпринимательского слоя в Воронежском крае. Особый интерес представляет ее статья, где рассматриваются вопросы становления мануфактурного предпринимательства в Воронежском крае, дается оценка мероприятий государственной поддержки (Павличенко, 2014).

На Западе исследованию Петровской эпохи уделяют достаточно большое внимание. С конца XIX в. американские и английские ученые сосредоточили свое внимание главным образом на изучении и написании подробной биографии Петра I. К их числу относятся Б. Саммер, М. Рэфф, М. Андерсон, Н. Рязановский, Л. Льюттер и др. (Summer, 1950; Raeff, 1963; Anderson, 1978; Riasanovsky, 1985; Lewitter, 1991). Все они восхваляли Петра I, одобряли его стремление направить Россию по европейскому пути развития.

Исследование деятельности Петра I продолжается в наше время в том же русле, что и прежде. Но некоторые авторы пытаются демонстрировать новые подходы, не ограничиваясь детальным 
изложением фактов из жизни Петра I. В Англии к их числу относится Линдсей Хьюз. В своей монографии о петровской России она не только показывает огромный масштаб личности Петра I, но и раскрывает результаты деятельности русского царя, характеризуя его нововведения во всех сферах жизни российского государства (Hughes, 2002).

В США определенной новизной отличается работа Пола Бушковича (Bushkovitch, 2001). В отличие от предшественников, он больше внимания уделил реформам Петра I, чем его личности, при этом справедливо подчеркивая, что царь достиг бы гораздо большего, если бы действовал последовательно, целеустремленно и решился бы на кардинальные преобразования государственного устройства.

Таким образом, как в России, так и на Западе ученые всегда проявляли большой интерес к Петровской эпохе, с той лишь разницей, что в Европе и США больше внимания уделяли личности Петра I, а у нас - результатам его деятельности.

\section{4. Результаты}

В истории Воронежского края, в его экономическом развитии большую роль сыграло начавшееся здесь строительство военно-морского флота в конце XVII века. И связано это событие, как известно, с именем императора Петра I.

Исходя из государственной целесообразности, Петр I считал необходимым обеспечить России выход к морям. В первую очередь он планировал возвратить Азов, захваченный турками еще в $\mathrm{XV}$ веке, и сделать его опорным пунктом дальнейшей борьбы за Черноморское побережье. Одновременно была бы решена и задача по защите южных границ России. Сухопутный поход на Азов в 1695 г. завершился неудачей. Стало ясно, что без флота не обойтись. И тогда Петр I принимает решение заложить верфь в Воронеже и начать здесь строительство военно-морского флота. Его намерение поддержала Боярская дума в октябре 1696 г.

Всего на Воронежской верфи в Петровскую эпоху было построено и спущено на воду более 100 военных судов (Лавринов, 1981: 78). Из-за мелководности рек Воронеж и Дон кораблестроение было перенесено в Тавров и продолжалось до начала 40-х годов XVIII в.

Судостроение оказало существенное влияние на социально-экономическое развитие Воронежского края, активизировало предпринимательскую деятельность. Новым явлением стало формирование здесь фабрично-заводской промышленности, которая наиболее широкое воплощение получила в металлургической и суконной отраслях.

Чтобы обеспечить бесперебойное снабжение флота всем необходимым, государство стало строить соответствующие мануфактуры за счет казенных средств. В 1700 г. началось создание Липецкого комплекса, состоявшего из трех металлургических и металлообрабатывающих заводов. Кроме того, государство выкупило Романовский металлургический завод (около города Романова), принадлежавший московским купцам Борину и Аристову (Павличенко, 2014: 53).

К металлургическому и металлообрабатывающему производству подключились и частные предприниматели. Государство такую инициативу всячески поощряло, так как рассматривало ее как дополнительную силу в ходе реализации поставленных задач. Оно снабжало их инструментами и орудиями производства, ссужало капиталом без процентов для строительства предприятий, выписывало мастеров из-за границы, освобождало заводчиков от государственной службы и т.п. Как правило, частные металлургические предприятия создавались на основе кустарных промыслов. Некоторые кузнецы, развивая свой профессионализм и активно торгуя на рынке, смогли сосредоточить в своих руках небольшие капиталы, что позволило им расширять производство и создавать мелкие и средние металлургические заводы. Только в Елецком уезде в первой четверти XVIII в. действовало до 20 таких заводов (Душкова, Августин, 2002: 26-27).

Но полноценными заводами они так и не смогли стать из-за слабой рудной базы. Районы с богатыми полезными ископаемыми осваивали казенные предприятия, поэтому частные заводы не смогли достигнуть уровня крупного вододействующего производства и оставались по большей части полукустарными.

Более крупные заводы были построены выходцами либо из Москвы (Василий Озеров), либо из Тулы (Василий Арехов), которые обладали гораздо большими капиталами.

Частные заводы, создаваемые с большим трудом, тем не менее продемонстрировали большую устойчивость по сравнению с казенными, которые по мере ослабления активности внешней политики России и истощения рудных запасов стали работать с перебоями и вскоре закрылись. Частные заводы просуществовали до конца XVIII века, переключившись на выпуск изделий для населения и реализацию ее по доступной цене.

В самом Воронеже также были металлургические предприятия, например, завод по литью медных пушек, колокольные заводы. Но насколько они были крупными, судить об этом сложно. Существуют различные оценочные высказывания, поэтому данный вопрос по-прежнему остается дискуссионным. А производственных дворов в Воронеже и его пригороде было достаточно много: токарного дела, якорных, пумповый, бочарный с кузницей, мозжерный и др. Всего в Воронеже и его окрестностях по переписи 1724 г. было 1532 двора, где проживали и строили свою деятельность 
ремесленники, купцы, однодворцы и пр. (Кретова, 1986: 35). Помимо кузнечного дела и металлообработки, они осваивали и другие виды предпринимательства, поэтому были также дворы горшечного дела, запасный, канатный, корабельный, кожевенный, прядильный, столярный, хамовный и др.

Немаловажную роль играли мастерские и лаборатории по изготовлению огнестрельного оружия, гранат, бомб и ядер. По-прежнему работало большое количество кузниц, в том числе медного котельного дела, якорные и др. Самые богатые и предприимчивые кустари-металлурги пытались все же создать свои предприятия, но не у всех это получалось.

Наряду с металлургической, успешно развивалась и суконная промышленность. Благоприятными сопутствующими факторами для этого являлись накопленные производственные навыки у жителей края, а также наличие дешевого местного сырья в виде шерсти. Первые казенные суконные фабрики были построены в с. Липском, а также Таврове. Их продукция полностью шла на нужды военного ведомства. Впоследствии фабрика в Таврове была передана группе лиц из числа дворян и купцов - Ф. Веневитинову, П. Гарденину, П. Лосеву, М. Плотникову, М. Тулинову и др. - в совместное частное содержание на льготных условиях, что отражало направленность правительственной политики на поддержку предпринимательской инициативы (Веселовский, 1886: 88).

При этом новые владельцы суконной фабрики должны были взять на себя обязательство закупать дополнительное оборудование, расширять производство и, самое главное, продолжать поставлять продукцию для военных нужд по государственным подрядам. А преимущество для них заключалось в том, что они могли производить дополнительную продукцию и беспошлинно ее продавать (ГАВО. Ф. И-18. Оп. 1. Д. 23. Л.16-18, 34).

В данном случае примечателен интерес дворянства к предпринимательству. Вложение ими средств в промышленное производство свидетельствовало о наличии у них довольно больших капиталов, стремлении их значительно увеличить и по возможности соответствовать новому времени.

К середине XVIII в. частных суконных мануфактур в Воронеже станет так много, что они образуют целые улицы: Левая Суконовка, Правая Суконовка. Первые собственники суконных фабрик дали начало целому ряду богатейших династий, к числу которых относятся Тулиновы, Гарденины и др. (Проторчина, 1961: 59-61).

На предприятиях в большинстве случаев применялся неэффективный и малопродуктивный ручной труд. Работали в основном покупные и приписные крестьяне. Исключение составляли частные заводы и фабрики, где использовался вольный найм из числа бывших кустарей. Рабочий день часто превышал 12 часов в сутки. Работали в сырых, грязных и холодных помещениях. За нарушение трудовой дисциплины применялись телесные наказания. В качестве борьбы с произволом владельцев предприятий использовался саботаж. Но, как правило, он был безуспешен. Иногда работные люди убегали с заводов, их ловили и вновь возвращали хозяину. Со временем воронежцы выбрали путь спасения от социальных и экономических бедствий через переселение, самовольный уход с насиженных мест дальше на юг, на реки Хопер, Битюг, Икорец, Дон. Наиболее отважные люди уходили даже на Кубань. Но не всем в этом случае сопутствовал успех (ГАВО. Ф. И-290. ОП. 2. Д. 1. Л. 1; Ф. И-14. Оп. 1. Д. 107. Л.1-2).

Кораблестроение, возросшая потребность в различной продукции для него способствовали сохранению и дальнейшему развитию в Воронежском крае широкого круга промыслов, самыми распространенными из которых являлись металлургические. Они сосредоточены были в местах залежи железной руды. Крестьяне добывали ее ручным способом и затем плавили в небольших «домницах» с помощью древесного угля. Полученное железо кустари продавали скупщикам. А те в свою очередь реализовывали его кузнецам, которые из него производили уже готовые изделия. В петровское время в Воронежском крае насчитывалось несколько десятков подобных «домниц». Владельцами этих примитивных кустарных металлургических предприятий могли быть представители из числа дворян, купцов, посадских людей и даже крестьян (Августин, 2007: 33-34).

Довольно успешно развивалось из-за возросшего спроса кожевенное дело. Производство кожи было издавна распространено в России, но способы обработки были весьма примитивны. Указ Петра I 1715 года ориентировал кожевенников использовать передовой западный опыт. Данный указ распространился и на воронежцев, которых обучали приглашенные иностранные специалисты. Качество кожевенной продукции значительно возросло, и она стала востребованной не только по всей России, но и за ее пределами. С кожевенным производством напрямую связано сапожное дело. Как правило, кто возделывал кожу, тот изготавливал и обувь. Эти виды промыслов были особенно прибыльными и позволяли кустарям накапливать капиталы, исчисляемые десятками тысяч рублей (Вейнберг, 1890: 87, 89).

Особую значимость в период кораблестроения в Воронежском крае приобрел мукомольный промысел. Он играл решающую роль в решении продовольственной проблемы в условиях резко возросшего числа населения. К концу XVIII в. здесь будет действовать более тысячи ветряных и водяных мельниц. Их владельцами обычно являлись или зажиточные крестьяне оброчных вотчин, или однодворцы (ГАВО. Ф. И-263. Оп. 1. Д. 316. Л. 1). 
Таким же прибыльным и распространенным был винокуренный промысел. Им издавна занимались повсеместно, изготавливая хмельные напитки разных сортов. При этом использовались рожь, ячмень, хмель, которые выращивались по берегам рек Воронеж и Дон. Увеличенный спрос на винокуренную продукцию способствовал созданию в течение непродолжительного времени винных заводов во многих городах края. Эти предприятия были оснащены современным по тем временам оборудованием и построены с использованием передового западного опыта, принадлежали они помещикам, а также состоятельным крестьянам (ГАВО. Ф. И-14. Оп. 1. Д. 20. Л. 180-182).

Большим спросом пользовалась готовая продукция кустарей и в других промыслах: гончарном, столярном, плотническом, токарном, кирпичном, бочарном, дегтярном, канатном, портном, чулочным и др. Для многих крестьян-кустарей промыслы становились основным занятием, а сельское хозяйство - второстепенным.

Строительство флота в Воронеже дало мощный импульс торговле, что в свою очередь привело к росту товарно-денежных отношений, оживления предпринимательской деятельности. Торговали преимущественно продукцией сельского хозяйства, животноводства, кустарных промыслов, но добавилась продукция металлургических и суконных мануфактур, а также горного промысла медь и железо.

Торговля осуществлялась на ярмарках, торгах и в лавках. Излишки производства вывозились в другие города, а ввозились недостающие товары. Это могли быть промышленные изделия, нарядная ткань, хрустальная, фарфоровая и серебряная посуда, галантерейная продукция, зеркала и прочие предметы роскоши.

В связи с правительственным указом 1711 г., разрешающим торговать представителям всех сословий, контингент желающих заниматься торговлей значительно расширился. В основном это происходило за счет сельских жителей, торговая деятельность которых способствовала накоплению капитала и стимулировала предпринимательскую активность. Однако по своему правовому положению они по-прежнему оставались крестьянами, что, безусловно, сковывало их инициативу.

В условиях жесткой сословной стратификации купеческий слой мог пополняться формально только за счет бывших служилых людей «по прибору», однодворцев, посадских людей. И даже в этом случае численность купцов была внушительной. В петровские времена в Воронеже их насчитывалось более полутора тысяч, что составляло почти половину мужского тяглового населения города (ГАВО. Ф. И-18. Оп. 1. Д. 23. Л. 68-69; Ф. И-18. Оп. 1. Д. 108. Л. 116-118). Из их среды стала выделяться наиболее зажиточная часть купечества, сумевшая обеспечить успех в делах и для своих последователей. Таким путем получили известность семьи Кривошеиных, Сахаровых, Русиновых и др. (ГАВО. Ф. И-171. Оп. 2. Д. 56. Л. 2-3).

Характерно, что в петровский период в связи с активизацией торговли воронежское купечество все больше и больше стало отходить от совмещения торговой и производственной деятельности и концентрироваться на продаже товаров, тем самым оно стало в большей мере соответствовать своему предназначению и сословию.

К расширению торговой деятельности подталкивал и рост населения в Воронеже. Работные люди прибывали сюда из разных городов России. Это были плотники, кузнецы и другие мастеровые люди, которые были задействованы в кораблестроении. Только в 1701 г. по указу Петра I в Воронеж было направлено 20 тысяч работников корабельного и стругового дела вместе с семьями из близлежащих регионов (Воронежский край в XVIII веке, 1980: 17-18). В результате увеличилась потребность в продуктах питания и бытовых предметах, что в свою очередь стимулировало торговлю.

Особую значимость в период судостроения в Воронеже приобретает сельское хозяйство. Увеличение численности населения вызвало небывалый рост производства сельхозпродукции. Возрастала площадь посевных угодий, увеличивалось количество огородов и садов, получило развитие животноводство и птицеводство. Сельское хозяйство становится основной отраслью экономики Воронежского края, и сюда активно проникают товарно-денежные отношения.

В качестве предпринимателей в сфере сельского хозяйства выступали дворяне, организовывая в своих поместьях производство растительной или животноводческой продукции на продажу. Другой категорией предпринимателей являлись представители купечества, мещанства, посадских людей. Их деятельность была связана с выращиванием бахчевых, садовых и огородных культур, созданием пасек. Третьей категорией были однодворцы, а также представители крестьянства (Болховитинов, 1800: 20).

Важным условием для расширения посевных площадей стали военные успехи Петра I на юге. После взятия русскими Азова и создания Азовского флота началось освоение левого берега Дона, а также плодородных земель к югу от Воронежа по берегам рек Хопер, Битюг, Икорец, Толучеева, Осереда. К занятию сельским хозяйством активно подключались служилые люди, по мере того как надобность в их функциях отпадала. Тем самым увеличивалось число занятых в аграрном секторе.

На продажу оптом в основном шли пшеница, рожь и другие зерновые культуры. Для их транспортировки необходимы были достаточно большие средства, которых не было у производителей. Эту функцию выполняли купцы-скупщики, накапливая тем самым значительные капиталы (ГАВО. Ф. И-14. Оп. 1. Д. 20. Л. 21 об., 31). 
Постепенно элементы предпринимательства и рыночных отношений внедряются и в сферу животноводства: разведение крупного рогатого скота, овцеводство, свиноводство. Достаточно прибыльным направлением стало коневодство. Первые конезаводы были созданы по указу Петра I в селах, расположенных по реке Битюг. Здесь стали разводить тяжеловозную породу лошадей. Но всемирную славу приобрел Хреновской конный завод графа А.Г. Орлова, построенный в Бобровском уезде чуть позже. На орловских рысаков был огромный спрос как в России, так и за рубежом (Кузнецов, 1978: 156).

Развитие предпринимательства среди крепостных крестьян позволило им накопить немалые капиталы. Это дало возможность некоторым из них впоследствии выкупиться на волю и даже стать основателями целых династий российской буржуазии. Так поступят, например, почти 3 тысячи крестьян графини А.А. Бутурлиной, выкупив себя с семьями и землей; а также более 4 тысяч крестьян помещицы А.Н. Стрекаловой (ГАВО. Ф. И-3О. Оп. 1. Д. 1287. Л. 3-4).

В обобщенном виде результаты предпринимательской деятельности в Воронежском крае представлены в Таблице 1.

Таблица 1. Основные показатели государственной и частной предпринимательской деятельности в Воронежском крае в первой четверти XVIII века (составлено по: ГАВО. Ф. И-18. Оп. 1. Д. 23. Л. 6-18; Павличенко, 2014: 53; Кретова, 1986: 35; Веселовский, 1886: 88; Григорова, 2011: 82; Очерки истории Воронежского края, 1961: 76)

\begin{tabular}{|c|c|c|}
\hline \begin{tabular}{l}
\multicolumn{1}{c}{ Торговое } \\
предпринима- \\
тельство
\end{tabular} & $\begin{array}{l}\text { Мануфактурное и кустарное } \\
\text { предпринимательство }\end{array}$ & $\begin{array}{l}\text { Предпринимательство в } \\
\text { сельском хозяйстве }\end{array}$ \\
\hline \begin{tabular}{l}
\multicolumn{1}{c}{ Сформировался } \\
купеческий слой. \\
В Воронеже \\
насчитывалось \\
более 1,5 тыс. \\
купцов, или 37,9 \% \\
от общей \\
численности \\
населения.
\end{tabular} & $\begin{array}{l}3 \text { металлургических и } \\
\text { металлообрабатывающих завода - } \\
\text { казенных; } \\
1 \text { завод по литью медных пушек - } \\
\text { казенный; } \\
3 \text { металлургических завода - частных; } \\
2 \text { колокольных завода - частных; } \\
2 \text { суконные фабрики - казенные; } \\
1 \text { кожевенный завод - казенный; } \\
7 \text { винокуренных заводов - частных; } \\
6 \text { крупных центров кустарной } \\
\text { металлургии. } \\
\text { Расширение спектра кустарных } \\
\text { промыслов: мукомольного, столярного, } \\
\text { токарного, кирпичного, канатного, } \\
\text { дегтярного и т.д. }\end{array}$ & $\begin{array}{l}\text { Товарными видами } \\
\text { производства становятся } \\
\text { выращивание зерновых } \\
\text { культур, развитие } \\
\text { овощеводства, производство } \\
\text { табака, разведение пчел. } \\
\quad \text { Прибыльными } \\
\text { направлениями товарного } \\
\text { животноводства выступали } \\
\text { коневодство, овцеводство, } \\
\text { разведение крупного рогатого } \\
\text { скота, свиней, коз. }\end{array}$ \\
\hline
\end{tabular}

Приведенные данные в таблице свидетельствуют об активизации предпринимательской деятельности в Воронежском крае в первой четверти XVIII века. Тем более если учесть, что в предшествующем веке были созданы лишь предпосылки для нее, такие как рост городов; развитие местной и донской торговли, кустарных промыслов; переориентация ремесленного производства на изготовление изделий не на заказ, а на продажу; появление такой категории населения, как оптовые скупщики. И формировались предпосылки для предпринимательства в условиях продолжавшегося процесса заселения края. При этом большинство населения составляли служилые люди, преимущественно служилые люди «по прибору», которые несли военную службу и одновременно занимались сельским хозяйством. А Воронеж только к концу XVII века стал превращаться из типичного пограничного города-крепости в центр ремесла и торговли.

Дальнейшему развитию предпринимательства и проникновению товарно-денежных отношений во все отрасли экономики препятствовало господство феодальной системы в стране. Дворянство рассчитывало в основном на усиление эксплуатации, а предприимчивые крестьяне не могли в полной мере развернуть свою деятельность, так как были ограничены крепостным правом.

\section{5. Заключение}

Таким образом, кораблестроение в Воронежском крае оказало существенное влияние на активизацию предпринимательской деятельности. Несмотря на сдерживающий фактор, каковым являлся феодализм, в его недрах стал формироваться предпринимательский слой. Этот процесс имел определенные особенности в данном регионе, хотя в целом проходил в русле общегосударственных тенденций. 
Главным достоянием этого периода явилось возникновение и развитие местной промышленности. Ведущая роль в строительстве заводов и фабрик принадлежала купечеству. Несмотря на то, что первые мануфактуры просуществовали недолго, первый опыт был получен.

Успехи в развитии промышленности, рост потребительского спроса оказали позитивное влияние на торговое предпринимательство. Правительство оказывало ему существенную поддержку, защищая его интересы.

В предпринимательскую деятельность были вовлечены и все категории сельского населения, но возможности у каждой из них были разные.

В хозяйственной жизни Воронежского края предпринимательство выглядело новым явлением, несвойственным феодализму. Но оно демонстрировало явное преимущество товарно-денежных отношений и начинало подрывать основы феодально-крепостнической системы.

Строительство военно-морского флота явилось значимым событием в истории России. Оно послужило локомотивом для экономического развития не только отдельных регионов, но и в целом всей страны, пусть даже феодальной. Доходы государства выросли в 3 раза, вывоз в 2 раза превышал ввоз, количество мануфактур увеличилось более чем в 10 раз, была заложена основа для горной, металлургической, перерабатывающей текстильной и военной промышленности, укрепился авторитет России среди европейских государств.

\section{Литература}

Августин, 2007 - Августин E.A. Кустарная металлургия Елецкого и Воронежского уездов в XVIII веке // Вестник Воронежского государственного технического университета. T. 3 . № 3 . Воронеж, 2007. С. 33-36.

Болховитинов, 1800 - Болховитинов E.A. Историческое, географическое и экономическое описание Воронежской губернии, собранное из истории, архивных записок и сказаний Е.А. Болховитиновым. Воронеж, 1800. 228 с.

Вейнберг, 1885 - Вейнберг Л.Б. Воронежский край: Исторический очерк. Вып. 1. Воронеж, 1885. $126 \mathrm{c}$.

Вейнберг, 1890 - Вейнберг Л.Б. Очерк сельскохозяйственной промышленности Воронежской губернии. Вып. 1. Воронеж, 1890. 126 с.

Веселовский, 1866 - Веселовский Г.М. Воронеж в историческом и современно-статистическом отношениях. С подробным планом города и его окрестностей. Воронеж, 1866. 316 с.

Веселовский, 1886 - Веселовский Г.М. Исторический очерк города Воронежа. 1586-1886. Воронеж, 1886. 298 с.

Воронежский край в XVIII веке - Воронежский край в XVIII веке. Документы и материалы по истории края. Сост. В.М. Проторчина. Воронеж, 1980. 176 с.

ГАВО - Государственный архив Воронежской области.

Григорова, 2011 - Григорова B.A. Роль кустарных промыслов в создании заводской металлургической базы Черноземного Юга России. Середина XVII - середина XVIII вB. Воронеж, 2011. $96 \mathrm{c}$.

Душкова, Августин, 2002 - Душкова Н.А., Августин Е.А. Металлургическая промышленность Черноземного Юга России. История и современность // Инженер. Технолог. Рабочий. 2002. № 10. C. 25-29.

История предпринимательства..., 2000 - История предпринимательства в России // Под ред. А.В. Семеновой. В 2-х кн. Кн. 1. М., 2000. 479 с.

Кретова, 1986 - Кретова О.К. Русский город Воронеж. Воронеж, 1986. 239 с.

Кузнецов, Рождественская, 1978 - Кузнецов И.А., Рождественская Г.А. Конный завод и порода: 200 лет Государственному конному заводу, родине орловского рысака. М., 1978. 156 с.

Лавринов, 1981 - Лавринов Ю.М. Работники Воронежских верфей: К истории воронежского кораблестроения 1696-1711 // Воронежский край на южных рубежах России (XVII-XVIII вв.). Воронеж, 1981. С. $75-83$.

Мизис, 2006 - Мизис Ю.А. Формирование рынка Центрального Черноземья во второй половине XVII - первой половине XVIII вв. Тамбов, 2006. 815 c.

Недосекин, 1960 - Недосекин В.И. Металлургическая промышленность Черноземного Центра России в середине XVIII в. // Вестник ВГПИ. Т. 31. Воронеж, 1960. С. 75-125.

Очерки истории Воронежского края, 1961 - Очерки истории Воронежского края // Под ред. Е.Н. Шуляковского. В 2-х т. Т. 1 Воронеж, 1961. 521 с.

Павличенко, 2014 - Павличенко О.И. Зарождение и развитие фабрично-заводского предпринимательства в Воронежском крае (конец XVII - XVIII вв.) // Вестник Самарского государственного университета. Гуманитарная серия. № 5. Самара, 2014. С. 51-55.

Проторчина, 1961 - Проторчина B.M. Суконная промышленность в Воронеже в XVIII веке // Из истории Воронежского края. Воронеж, 1961. С. 57-71.

Anderson, 1978 - Anderson, M.S. (1978). Peter the Great. London, 276 p. 
$346 \mathrm{p}$.

Bushkovitch, 2001 - Bushkovitch, P. (2001). Peter the Great. Lanham, Boulder, New-York, Oxford.

Hughes, 2002 - Hughes, L. (2002). Peter the Great. A Biography. New Haven and London, 405 p.

Lewitter, 1991 - Lewitter, L.R. (1991). Peter the Great and contemporary world. London, 347 p.

Raeff, 1963 - Raeff, M. (1963). Peter the Great: Reformer or Revolutionary? Lexington (Mass), 247 p.

Riasanovsky, 1985 - Riasanovsky N.V. The Image of Peter the Great in Russian History and Thought.

New-York-Oxford: Oxford Press. 1985. 153 p.

Summer, 1950 - Summer B.H. Peter the Great and the emergence of Russia. New-York, 1950. 187 p.

\section{References}

Anderson, 1978 - Anderson, M.S. (1978). Peter the Great. London. 276 p.

Avgustin, 2007 - Avgustin, E.A. (2007). Kustarnaya metallurgiya Eletskogo i Voronezhskogo uezdov v XVIII veke [Handicraft metallurgy of Yelets and Voronezh districts in a XVIII-th century]. Vestnik Voronezhskogo gosudarstvennogo tekhnicheskogo universiteta. T. 3. № 3. Voronezh. pp. 33-36. [in Russian]

Bolkhovitinov, 1800 - Bolkhovitinov, E.A. (1800). Istoricheskoe, geograficheskoe i ehkonomicheskoe opisanie Voronezhskoi gubernii, sobrannoe iz istorii, arkhivnykh zapisok i skazaniya E.A. Bolkhovitinovym [Historical, geographical and economic description of the Voronezh province, collected from the history, archival notes and legends by E.A. Bolkhovitinov]. Voronezh. 228 p. [in Russian]

Bushkovitch, 2001 - Bushkovitch, P. (2001). Peter the Great. Lanham, Boulder, New-York, Oxford. $346 \mathrm{p}$.

Dushkova et al., 2002 - Dushkova, N.A., Avgustin, E.A. (2002). Metallurgicheskaya promyshlennost' Chernozemnogo Yuga Rossii. Istoriya i sovremennost' [Metallurgical industry of the Chernozem South of Russia. History and modernity]. Inzhener. Tekhnolog. Rabochii. 10: 25-29. [in Russian]

GAVO - Gosudarstvennyi arkhiv Voronezhskoi oblasti [State archive of the Voronezh Region].

Grigorova, 2011 - Grigorova, V.A. (2011). Rol' kustarnykh promyslov v sozdanii zavodskoi metallurgicheskoi bazy Chernozemnogo Yuga Rossii. Seredina XVII - seredina XVIII vv. [The role of handicrafts in the creation of a metallurgical plant base in the Chernozem South of Russia. Mid-XVII - midXVIII centuries]. Voronezh. 96 p. [in Russian]

Hughes, 2002 - Hughes, L. (2002). Peter the Great. A Biography. New Haven and London. 405 p.

Istoriya predprinimatel'stva..., 2000 - Istoriya predprinimatel'stva v Rossii (2000) [The history of entrepreneurship in Russia]. Pod red. A.V. Semenovoi. (2000). V 2-kh KN. Kn. 1. M. 479 p. [in Russian]

Kretova, 1986 - Kretova, O.K. (1986). Russkii gorod Voronezh [Russian city of Voronezh]. Voronezh. 239 p. [in Russian]

Kuznetsov et al., 1978 - Kuznetsov, I.A. (1978). Rozhdestvenskaya G.A. (1978). Konnyi zavod i poroda: 200 let Gosudarstvennomu konnomu zavodu, rodine orlovskogo rysaka [Stud farm and breed: 200 years of the State Stud Farm, the birthplace of the Orel trotter]. M. 156 p. [in Russian]

Lavrinov, 1981 - Lavrinov, Yu.M. (1981). Rabotniki Voronezhskikh verfei: K istorii voronezhskogo korablestroeniya 1696-1711 [Employees of Voronezh shipyards: On the history of Voronezh shipbuilding 1696-1711]. Voronezhskii krai na yuzhnykh rubezhakh Rossii (XVII-XVIII vv.). Voronezh. Pp. 75-83. [in Russian]

Lewitter, 1991 - Lewitter, L.R. (1991). Peter the Great and contemporary world. London. 347 p.

Mizis, 2006 - Mizis, Yu.A. (2006). Formirovanie rynka Tsentral'nogo Chernozem'ya vo vtoroi polovine XVI - pervoi polovine XVIII vv. [Formation of the Central Chernozem Region market in the second half of the XVII - first half of the XVIII centuries]. Tambov. 815 p. [in Russian]

Nedosekin, 1960 - Nedosekin, V.I. (1960). Metallrugicheskaya promyshlennost' Chernozemnogo Tsentra Rossii v seredine XVIII v. [Metallurgical industry of the Chernozem Center of Russia in the middle of the XVIII century]. Vestnik VGPI. T. 31. Voronezh. Pp. 75-125. [in Russian]

Ocherki istorii Voronezhskogo kraya, 1961 - Ocherki istorii Voronezhskogo kraya (1961). [Essays on the history of the Voronezh Region]. Pod red. E.N. Shulyakovskogo. (1961). V 2-kh t. T. 1 Voronezh. 521 p. [in Russian]

Pavlichenko, 2014 - Pavlichenko, O.I. (2014). Zarozhdenie i razvitie fabrichno-zavodskogo predprinimatel'stva v Voronezhskom krae (konets XVII - XVIII vv.) [The origin and development of factory entrepreneurship in the Voronezh Region (late XVII-XVIII centuries)]. Vestnik Samarskogo gosudarstvennogo universiteta. Gumanitarnaya seriya. 5. Samara. Pp. 51-55. [in Russian]

Protorchina, 1961 - Protorchina, V.M. (1961). Sukonnaya proimyshlennost' v Voronezhe v XVIII veke

[Cloth industry in Voronezh in the XVIII century]. Iz istorii Voronezhskogo kraya. Voronezh. Pp. 57-71. [in Russian]

Raeff, 1963 - Raeff, M. (1963). Peter the Great: Reformer or Revolutionary? Lexington (Mass). 247 p. Riasanovsky, 1985 - Riasanovsky, N.V. (1985). The Image of Peter the Great in Russian History and Thought. New-York-Oxford: Oxford Press. 153 p.

Summer, 1950 -Summer, B.H. (1950). Peter the Great and the emergence of Russia. New-York. 187 p. 
Veinberg, 1885 - Veinberg, L.B. (1885). Voronezhskii krai: Istoricheskii ocherk [Voronezh Region: A historical essay]. Vyp. 1. Voronezh, 126 p. [in Russian]

Veinberg, 1890 - Veinberg, L.B. (1890). Ocherk sel'skokhozyaistvennoi promyshlennosti Voronezhskoi gubernii [An essay on the agricultural industry of the Voronezh province]. Vyp. 1. Voronezh. 126 p. [in Russian]

Veselovskii, 1866 - Veselovskii, G.M. (1866). Voronezh v istoricheskom i sovremenno-statisticheskom otnosheniyakh. S podrobnym planom goroda i ego okrestnostei [Voronezh in historical and modernstatistical relations. With a detailed plan of the city and its surroundings]. Voronezh. 316 p. [in Russian]

Veselovskii, 1886 - Veselovskii, G.M. (1886). Istoricheskii ocherk goroda Voronezha. 1586-1886 [A historical sketch of the city of Voronezh. 1586-1886]. Voronezh. 298 p. [in Russian]

Voronezhskii krai v XVIII veke - Voronezhskii krai v XVIII veke. Dokumenty i materialy po istorii kraya, 1980 - Voronezhskii krai v XVIII veke. Dokumenty i materialy po istorii kraya (1980) [Voronezh Region in the XVIII century. Documents and materials on the history of the region]. Sost. V.M. Protorchina. Voronezh. 176 p. [in Russian]

\section{Кораблестроение в Воронежском крае в Петровскую эпоху и его влияние на рост предпринимательской активности}

\section{Наталия Александровна Душкова а , *, Лариса Ивановна Маслихова а}

а Воронежский государственный технический университет, Российская Федерация

Аннотация. Статья посвящена проблеме роста предпринимательской активности в Воронежском регионе под воздействием кораблестроения в Петровскую эпоху. Она проявилась прежде всего в строительстве частных металлургических заводов, суконных фабрик. Авторы раскрывают государственные меры поддержки частных владельцев, характеризуют преимущества частных предприятий перед казенными. Определенное внимание уделено выявлению причин сохранения и дальнейшего развития широкого круга промыслов, наряду с мануфактурным производством.

Большое место в статье уделено процессу расширения предпринимательского слоя в торговле. Исследован социальный состав воронежских купцов, отмечен факт произошедшей усиленной специализации торгового слоя в петровский период, что привело впоследствии к формированию купеческого сословия в полном смысле слова.

Авторы подчеркивают особую значимость сельского хозяйства в период судостроения в Воронеже, которое становится основной отраслью экономики ёкрая. Они выделяют три категории населения, которые проявили предпринимательскую активность в данной сфере и значительно преуспели в своем деле.

Постепенно элементы предпринимательства и рыночных отношений внедряются, как подчеркивают авторы, и в сферу животноводства. В статье рассматриваются самые прибыльные направления товарного животноводства, а также самые распространенные виды предпринимательства в данной отрасли.

В работе отмечаются положительные результаты от предпринимательской активности, указаны преимущества, полученные разными категориями населения от этой деятельности, показан экономический эффект.

Все это свидетельствует о том, что судостроение послужило хорошим стимулом для предпринимательской деятельности, экономического подъема Воронежского края.

Ключевые слова: кораблестроение, предпринимательство, производство, мануфактура, металлургия, промыслы, кустари, купечество, сельское хозяйство.

\footnotetext{
${ }^{*}$ Corresponding author

E-mail addresses: dushkova12@mail.ru (Н.А. Душкова)
} 